\title{
PREGNANT WOMEN AT WORK
}




\title{
PREGNANT WOMEN AT WORK
}

\author{
Edited by
}

\section{GEOFFREY CHAMBERLAIN}

Professor of Obstetrics and Gynaecology

St George's Hospital Medical School

Cranmer Terrace, London SWI7 ORE 
(C) The Royal Society of Medicine 1984

Softcover reprint of the hardcover 1st edition 1984 978-0-333-36881-7

All rights reserved. No part of this publication may be reproduced or transmitted, in any form or by any means, without permission

First published jointly in 1984 by

THE ROYAL SOCIETY OF MEDICINE

1 Wimpole St, London WIM 8AE

and

The Scientific and Medical Division

THE MACMILLAN PRESS LTD

London and Basingstoke

Companies and representatives throughout the world

British Library Cataloguing in Publication Data

Chamberlain, Geoffrey

Pregnant women at work.

1. Pregnant women - Great Britain

2. Women - Employment - Great Britain

I. Title

$331.4^{\prime} 3^{\prime} 0941 \quad$ RG 525

ISBN 978-0-333-37117-6 ISBN 978-1-349-86031-9 (eBook)

DOI 10.1007/978-1-349-86031-9 


\section{Contents}

The contributors vii

Foreword Sir James Watt ix

Preface Geoffrey Chamberlain xi

PART 1 THE CURRENT SITUATION 1

1 WOMEN AT WORK IN PREGNANCY Geoffrey Chamberlain 3

2 THE EFFECT OF WORK ON PLACENTAL FUNCTION 15

AND FETAL GROWTH Frank E. Hytten

3 THE HAZARDS OF WORK IN PREGNANCY Rober Murray 27

4 WOMEN WORKERS AT HIGHER RISK OF REPRODUCTIVE 35

HAZARDS Raja W. Abdul-Karim

5 REPRODUCTIVE HAZARDS OF THE AMERICAN LIFE STYLE Steven G. Gabbe

6 BIRTH DEFECTS AND PARENTAL OCCUPATION 61

J. David Erickson

7 THE EPIDEMIOLOGICAL IDENTIFICATION OF REPRO- 73

DUCTIVE HAZARDS Michael E. McDowall

8 THE EFFECTS OF WORK IN PREGNANCY: SHORT- AND 87 LONG-TERM ASSOCIATIONS Timothy J. Peters, Philippa Adelstein, Jean Golding and Neville R. Butler

9 OCCUPATIONAL FATIGUE AND PRETERM BIRTH 105 Nicole Mamelle and Bernard Laumon

10 THE EFFECT OF THE MOTHER'S WORK ON THE INFANT Ann Oakley 
11 MECHANISMS OF TERATOGENESIS: THE EXTRAPOLATION OF THE RESULTS OF ANIMAL STUDIES TO MAN E. Marshall Johnson

12 WHAT EVIDENCE IS REQUIRED TO IDENTIFY A CHEMICAL AS A REPRODUCTIVE HAZARD? Donald $R$. Mattison

13 ANIMAL AND HUMAN STUDIES IN GENETIC TOXICOLOGY Marvin S. Legator and Jonathan B. Ward

\section{PART 3 RESPONSES}

14 A TRADE UNION VIEW OF REPRODUCTIVE HEALTH Sheila McKechnie

15 A MANAGEMENT VIEW OF REPRODUCTIVE HEALTH Jonathan Plaut

16 LEGAL CONSIDERATIONS OF REPRODUCTIVE HAZARDS IN INDUSTRY IN THE UNITED KINGDOM Steven J. Lorber

17 LEGAL CONSIDERATIONS OF REPRODUCTIVE HAZARDS IN INDUSTRY IN THE UNITED STATES Nicholas $A$. Ashford

18 WHAT CAN BE DONE IN ANTENATAL CARE? Ann Foster

19 THE CONTRIBUTION OF THE OCCUPATIONAL HEALTH SERVICES Frances J. T. Baker

20 EDUCATING WORKERS, MANAGEMENT AND THE

GENERAL PUBLIC James McEwen

\section{PART 4 CONCLUSIONS}

21 FUTURE RESEARCH ON WORK IN PREGNANCY

Jo Garcia and Diana Elbourne

22 ADVERSE INFLUENCES OF THE WORKING ENVIRONMENT Geoffrey Chamberlain 


\section{The Contributors}

Prof Raja W. Abdul-Karim

Dept of Obstetrics and Gynecology

College of Medicine

State University of New York

Upstate Medical Center

750 East Adams St

Syracuse, NY 13210

USA

Nicholas A. Ashford

Center for Policy Alternatives

Massachusetts Institute of Technology

Cambridge

Mass 02139

USA

Ms Frances J. T. Baker

Senior Nursing Officer

Scottish Gas

Granton House

4 Marine Drive

Edinburgh EH5 1YB

Prof N. R. Butler

Dept of Child Health

Royal Hospital for Sick Children

St Michael's Hill

Bristol BS2 8BJ

Prof Geoffrey Chamberlain

Dept of Obstetrics and Gynaecology

St George's Hospital Medical School

Cranmer Terrace

London SW17 ORE
Dr J. David Erickson

Chronic Diseases Division

Center for Environmental Health

Centers for Disease Control

Atlanta

Georgia 30333

USA

\author{
Miss Ann Foster \\ EMAS Branch D \\ Health and Safety Executive \\ 25 Chapel Street \\ London NW1 5DT
}

\section{Dr Steven G. Gabbe}

Hospital of the University of Pennsylvania Woman's Hospital Division

3400 Spruce Street

Philadelphia, Pa 19104

USA

Ms Jo Garcia

National Perinatal Epidemiology Unit

Radcliffe Infirmary

Oxford OX2 6HE

Dr F. E. Hytten

Division of Perinatal Medicine

Clinical Research Centre

Medical Research Council

Watford Road

Harrow, Middlesex

HA1 3UJ 


\section{viii The Contributors}

Dr E. Marshall Johnson

Director

Daniel Baugh Institute of Anatomy

Jefferson Medical College

Thomas Jefferson University

1020 Locust Street

Philadelphia

Pa 19107

USA

Prof Marvin S. Legator

Dept of Preventive Medicine and

Community Health

Division of Environmental Toxicology

The University of Texas Medical Branch

25 Keiller Building, F-19

Galveston

Texas 77550

USA

Mr Steven Lorber

North Islington Law Centre

161 Hornsey Road

London N7 6DU

Mr M. E. McDowall

Medical Statistics Division

Office of Population Censuses and Surveys

St Catherine's House

10 Kingsway

London WC2B 6JP

Dr James McEwen

Academic Dept of Community Medicine

King's College Hospital Medical School

Denmark Hill

London SE5 8RX

Ms Sheila McKechnie

Health and Safety Officer

ASTMS

Whitehall Office

Dane O'Coy's Road

Bishops Stortford

Herts
Dr N. Mamelle

INSERM - U170

Université Claude Bernard - Bâtiment 710

La Doua

43 Boulevard du Onze Novembre

69100 Villeurbanne Cedex

France

Dr Donald R. Mattison

Building 10, Room 8C313

Pregnancy Research Branch

National Institute of Child Health and

Human Development

National Institutes of Health

Bethesda

Maryland 20205

USA

Dr Robert Murray OBE

Consultant in Occupational Health

120 Temple Chambers

Temple Avenue

London EC4Y ODT

Dr Ann Oakley

National Perinatal Epidemiology Unit

Radcliffe Infirmary

Oxford

OX2 6 HE

Mr Jonathan Plaut

Environmental Affairs

Allied Corporation

PO Box 1057R

Morristown

NJ 07960

USA

Sir James Watt

President

Royal Society of Medicine

1 Wimpole St

London W1M 8AE 


\title{
Foreword
}

\author{
Sir James Watt \\ President, Royal Society of Medicine
}

Sir Richard Doll once warned crusaders about the formidable hurdles they can expect to encounter in their attempts to protect patients against health hazards. The value of preventive measures may be extremely difficult to prove: they necessarily enter the cost-benefit equation, but costs and benefits are as much susceptible to subjective assessment as to objective quantification. Ultimately, preventive measures may prove so expensive that authorities might prefer to spend the money on clinical care with its more tangible benefits ${ }^{1}$. Nevertheless, despite such discouragement, Williams has suggested that we are effectively safeguarding the patient's welfare when 'the most valuable thing that we are not doing is less valuable than the least valuable thing that we are doing' ${ }^{2}$.

One problem in our modern society is that more women are working in pregnancy in a wide variety of occupations. They are concerned about the effects of their work on the outcome of pregnancy. What information there is about the hazards of working at this time is spread diffusely, and large areas exist where we have no firm answers. Because of the importance of this aspect of preventive health, the Royal Society of Medicine and the Royal Society of Medicine Foundation made it the subject of their 1983 Anglo-American Conference. The idea was inspired by the interest of Professor Geoffrey Chamberlain, who has drawn attention to apparent anomalies and conflicting observations which raise many questions, but provide few answers ${ }^{3}$. Strictly comparable data have been difficult to obtain, owing to the large number of variables, such as age, social class, marriage patterns, family size, social benefits, antenatal screening, the nature of the work and the transportation conditions, management philosophy, staffing facilities, diet, national traditions of employment and the effectiveness or otherwise of safety regulations in different countries.

The participants of the conference obviously realised this during the spirited discussion, the hallmark of a meeting's success; the speakers were subjected to searching probes and suggestions for action from a particularly well-informed and perceptive audience. It became evident that a collaborative and integrated 


\section{$\mathrm{x}$ Foreword}

approach to the problems of pregnant women at work will be necessary, involving practical industrial measures, effective legislation, education and research. The Editor, Professor Geoffrey Chamberlain, is therefore to be congratulated upon arranging the publishing of the proceedings of this symposium with a minimum of delay.

\section{REFERENCES}

1. Doll, Sir Richard (1982). Prospects for Prevention. The Harveian Oration, Royal College of Physicians, London

2. Williams, A. (1978). Efficiency and welfare. In Providing for the Health Services, Black, D. and Thomas, S. P. (Eds.), Croom Helm, London

3. Chamberlain, G. and Garcia, J. (1983). Pregnant women at work. Lancet, 1, 228-230 


\section{Preface}

The catalyst for this book was the Anglo-American Conference held in the summer of 1983 at the Royal Society of Medicine in London. These conferences are held alternately in London and Washington, their purpose being to bring together experts from both sides of the Atlantic to discuss subjects which have repercussions in each country. On this occasion the subject chosen was that of how the work a woman does in pregnancy may affect her health or that of her unborn child. It was decided that we should take the opportunity of bringing so many experts together to produce a volume on the subject in parallel with the meeting. Those speaking came from many disciplines, including obstetrics, epidemiology, pathology, toxicology, occupational health and the law. They each had at their fingertips original and published material from their own discipline, much of which was unknown to those who worked in other aspects of the subject. In consequence, each speaker was asked to contribute a chapter on that aspect of the subject in which he or she was expert, so that one volume could be produced containing material that would be of help to anyone wishing to look into the subject in the future. Particular value is in the large numbers of references given by each contributor, which may lead to further reading.

One of the values of a conference such as 'Pregnant Women at Work' is that it stimulates ideas for doing further research. Each of us realises the deficiencies of our own present knowledge, and the stimulation of meeting other people with slightly different approaches to the same subject produces ideas for new projects. It is hoped that, by disemminating more widely the ideas of the contributors to this conference, others might be able to react to the stimulation. It was decided not to publish the discussion which occurred after each paper, but the editor has grouped together some of the issues considered in a concluding chapter entitled 'Adverse influences of the working environment'.

No volume of this nature could be produced without a lot of co-operation from many workers. The editor is grateful to all the contributors who produced their manuscripts so promptly and allowed publication to proceed at a brisk 


\section{xii Preface}

pace. He is grateful to The Macmillan Press, the publishers, for their expeditious dealing with the matter. Finally, all of us owe a debt to Miss Muriel Mitchell of the Royal Society of Medicine, who so ably organised the conference and whose grasp of the principles and details of running such a meeting has proved invaluable to many at the RSM.

London, 1984

G. C. 